DOI https://doi.org/10.30525/978-9934-26-148-0-24

\title{
ЩОДО ПИТАННЯ ВПРОВАДЖЕННЯ «СИРІТСЬКИХ ТВОРІВ» У АВТОРСЬКЕ ПРАВО УКРАЇНИ
}

\author{
Майданик Л. Р. \\ дочент кафедри інтелектуальної власності та інформаційного права \\ Інституту права Київського національного університету \\ імені Тараса Шевченка \\ м. Київ, Україна
}

Укладення Угоди про асоціацію між Україною та Європейським Союзом визначило конкретні напрямки та способи наближення законодавстсва України з питань інтелектуальної власності до права ЄС. Крім того, цифровий розвиток суспільства обумовлює введення нових для вітчизняного законодавства інститутів. Актуалізації вимагають окремі положення щодо обмежень авторського права і суміжних прав з точки зору прийнятих європейських підходів задля забезпечення ефективного балансу приватного і публічного інтересів, а також збереження та поширення культурної спадщини.

Зокрема, слід доповнити перелік випадків вільного використання об'єктів авторського права і суміжних прав в частині відтворення об'єктів, що вибули 3 комерційного обігу [1]; врахувати європейські підходи щодо сирітських творів із можливістю бібліотек, архівів та музеїв створення цифрових примірників таких об'єктів в передбачених законом випадках; врахувати положення Угоди про асоціацію щодо інших обмежень, зокрема щодо баз даних (ст. 188 Угоди про асоціацію); забезпечити єдине розуміння права слідування відповідно до змісту ст. 190 Угоди про асоціацію, що потребує внесення змін до Цивільного кодексу України та ЗУ «Про авторське право і суміжні права». У цілях цієї роботи розглядатиметься лише питання сирітських творів, хоча серед дослідників існує позиція про ширше розуміння, яке включає у себе і твори, які вибули з комерційного обігу [2].

Щодо законодавства Європейського Союзу з питання сирітських творів, то 25 жовтня 2012 року була прийнята Директива 2012/28/EU щодо деяких можливостей використання сирітських творів. Згідно 3 Директивою, право поширення сирітських творів мають виключно некомерційні культурні заклади, тобто музеї, архіви, бібліотеки, після спроби знайти власника майнових авторських прав. Доступ при цьому може здійснюватися лише в електронній формі. 
Німеччина стала першою країною в Європейському Союзі, що імплементувала норми цієї Директиви. Відповідно до правок, що були внесені до Закону Німеччини «Про авторське право і суміжні права», оцифровувати та розміщувати у вільному он-лайн доступі сирітські твори уповноважені заклади (такі як публічні бібліотеки, державні наукові і учбові заклади) можуть лише після пошуку автора або особи, що має авторське право на такий твір. Цей пошук, у тому числі, можна провести за допомогою баз даних організацій колективного управління, що діють у Німеччині.

Законодавство України не розглядає проблематику сирітських творів, у країні відсутні й грунтовні дослідження щодо цієї проблематики. I хоча в Україні термін дії авторських прав дещо нижчий, ніж в США чи Великобританії, проблема сирітських творів все ж існує, тому не правильним вбачається ії ігнорування на законодавчому рівні. Крім того, враховуючи те, що Україна підписала Угоду про асоціацію з СС, необхідною $є$ імплементація положень Директиви 2012/28/EU до національного законодавства.

Тому, на наш погляд, слід створити он-лайн архів сирітських творів. За допомогою цього архіву можна буде як надавати доступ до цих творів, так і передбачити процедуру, за якої автор зможе вилучити свій «загублений» твір із цього архіву і знову користуватися своїми правами.

У випадку, коли твір набуває статус «сирітського», він потрапляє до он-лайн бази, де всі охочі, сплативши відповідно до ліцензії певну грошову суму, зможуть користуватися фотографією у комерційних чи інших цілях. Однак якщо ії автор побачить свій твір у такому архіві, він зможе подати прохання, надавши документи, що підтверджують його авторство, чи те, що він $є$ правоволодільцем, та вилучити фотографію 3 цього архіву. Робота такого типу он-лайн архіву фактично є схожою 3 роботою фотобанків та має грунтуватися на тих же засадах у своєму функціонуванні.

Частина країн Європейського Союзу покладає функції зі створення реєстру сирітських творів на організації колективного управління, зокрема, Німеччина. Пошук автора чи особи, що має авторське право на такий твір, дійсно доцільно реалізовувати з урахуванням створення архівних баз організацій колективного управління та професійних спілок, що захищають авторські права. Для цього необхідно надати цим організаціями в Україні можливість на правових засадах здійснювати ідентифікацію відповідних видів творів, а також їх авторів або осіб, яким належить авторське право.

В контексті перспектив щодо впровадження таких правових конструкцій в Україні, то функції щодо надання ліцензій на викорис- 
тання творів, щодо яких не можливо встановити особу автора, та строк охорони якого не закінчився, доцільно покласти на Національний орган інтелектуальної власності України, функції якого на сьогоднішній день виконує Державне підприємство «Український інститут інтелектуальної власності». Так, в Проекті Закону «Про авторське право і суміжні права» [3], розроблений Міністерством економіки України, стаття 1 визначає сирітський твір (виконання, фонограма, відеограма) як твір (виконання фонограма, відеограма), щодо яких жоден з суб'єктів авторського права i (або) суміжних прав у цьому творі (виконані фонограмі, відеограмі) не ідентифікований, чи навіть якщо один або кілька з них ідентифіковані, але жоден 3 них не знайдений, незважаючи на належний розшук цих суб'єктів, що проводився та фіксувався.

Законопроект в ст. 31 передбачає умови визнання твори сирітським, а також способи його використання. Так, допускається використання сирітських творів способами відтворення (3 метою оцифрування, доведення до загального відома публіки шляхом інтерактивного надання електронного (цифрового) доступу, індексації, каталогізації, збереження або відновлення копії), а також доведення до загального відома публіки шляхом інтерактивного надання доступу публіці після вжиття заходів із ідентифікації та належного розшуку авторів, інших суб'єктів авторського права, які не призвели до ідентифікації відповідних суб'єктів авторського права або віднайдення ідентифікованих суб' єктів.

Сирітський твір (фонограма, відеограма) у згаданому проекті закону розглядається не лише у контексті авторського права, а й суміжних прав, зокрема, щодо фонограм та відеограм, що видається обгрунотованим. Так, ст. 46 проекту закону Допускається використання сирітських виконань, фонограм, відеограм у випадках передбачених частиною першою статті 31 цього Закону щодо сирітських творів.

Загалом, пропозиція щодо сритіських творів у авторському праві України є позитивним кроком щодо досягнення балансу між правами автора та суспільства. Разом з тим, потребує допрацювання пололження щодо порядку визнання та втрати статусу «сирітських» творами в частині повноважень уповноваженого на це органу. Так, запропоновано передати ці функції. ДП «Укрпатент», який за заявами зацікавлених осіб зможе приймати рішення за певних умов, зокрема вжиття заходів щодо ідентифікації та розшуку автора та/або правоволодільця. Також, пропонується запровадити реєстрацію сирітських творів указаним уповноваженим органом та відображення такої інформації у зведеній пошуковій базі даних - Спеціальній інформаційній системі Укрпатенту. 


\title{
Література:
}

1. Троцька В. Правові аспекти використання бібліотеками та іншими закладами творів, що вийшли з комерційного обороту. Теорія $i$ практика інтелектуальної власностію. 2021. № 2. С. 5-15.

2. David R. Hansen, , Orphan Works: Definitional Berkeley Digital Library Copyright Project White Paper No. 1, URL: https://ssrn.com/ abstract=1974614 or http://dx.doi.org/10.2139/ssrn.1974614

3. Проект Закону «Про авторське право i суміжні права» URL: https://www.me.gov.ua/Documents/Detail?title=ProktZakonuUkrainiproAvtorskePravoISumizhniPrava

DOI https://doi.org/10.30525/978-9934-26-148-0-25

\section{ФРАУДАТОРНИЙ ПРАВОЧИН З ПОЗИЦІЇ СУДОВОЇ ПРАКТИКИ}

\author{
Сівіцька Г. С. \\ здобувач вищої освіти юридичного відділення \\ Галищького коледжу імені В'ячеслава Чорновола
}

\section{Гелецька I. O.}

кандидат юридичних наук, дочент кафедри права Галицького коледжу імені В 'ячеслава Чорновола

м. Тернопіль, Украӥна

Фраудаторний правочин - доволі нове поняття для українського законодавства, оскільки судова практика вперше почала його використовувати лише у 2019 році. Такі правочини характеризуються як такі, що укладаються боржником з метою запобігання зверненню стягнення на майно, а це призводить до того, що боржниками майно реалізується поза межами виконавчого провадження i, як наслідок, судові рішення залишаються невиконаними. Факт застосування терміну «фраудаторний правочин» привернув увагу правничої спільноти та став предметом обговорення серед багатьох вчених. При цьому актуальним для діючого цивільного законодавства залишається проблема формування єдиної правозастосовчої практики у справах про визнання недійсним правочину вчиненого боржником на шкоду кредиторові.

Варто зазначити, що науковий пошук 3 питань недійсності правочинів був предметом дослідження багатьох вчених, таких як: 